\title{
The use of partitive predicatives by Estonian learners of Finnish at different levels of $L 2$ proficiency
}

\author{
MARIANNE SPOELMAN \\ University of Oulu
}

\begin{abstract}
The partitive has often been acknowledged as problematic for L2 learners of Finnish. The purpose of this study was to identify possible instances of L1 influence in Estonian learners' use of partitive predicatives and to explore the relation between L1 influence and L2 proficiency. Research materials (85,749 words) were selected from the Estonian subcorpus of the International Corpus of Learner Finnish and evaluated according to the CEFR proficiency scales (i.e. A1-C2). A frequency-error analysis revealed instances of both positive L1 influence (e.g. a virtual lack of partitive overuse errors) and negative L1 influence (e.g. frequent use of nominative plural instead of partitive plural predicatives). The latter error type was found to ultimately decrease with increasing L2 proficiency, suggesting an inverse relation between negative L1 influence and L2 proficiency. Nonetheless, interactions between L1 influence and several other variables also reflected the extremely complex nature of the phenomenon of L1 influence.
\end{abstract}

Keywords: L1 influence; learner language; corpus research; partitive; copula construction; Finnish; Estonian 


\section{Introduction}

The partitive, a typical case characterizing the Finnic languages (Kiparsky 1998), gradually developed from a locative case with separative meaning (e.g. kotoa 'from home') into a case expressing more abstract syntactic relationships (Denison 1957). In modern Finnish, the partitive is one of the most frequently used cases; and it is first and foremost used as an object, subject and predicative case indicating partiality, quantitative unboundedness, negative polarity or aspectual unboundedness. Based on both teaching (e.g. Schot-Saikku 1990) and personal experiences (e.g. Denison 1957), the use of the partitive case has often be acknowledged as problematic for learners of Finnish as a foreign language. It has, however, not extensively nor systematically been investigated what exactly makes the use of the Finnish partitive difficult, what learners' main points of difficulty are and which of these are shared by all groups of learners or specific to a certain group of learners. Therefore, the current study adopts a corpus-based approach in order to investigate learners' use of partitive predicatives. The purpose of this study with special reference to Estonian learners of Finnish as a foreign language at different levels of foreign language proficiency is to provide insights into the role of the first language (L1) in the use of partitive predicatives and the interaction between possible L1 influence and foreign language proficiency in this.

In what follows, the Finnish and Estonian copula construction will be discussed and differences between Finnish and Estonian predicative case-marking will be indicated. Subsequently, the phenomenon of L1 influence will be introduced. As the current study is part of an ongoing research project on the use of the partitive case in Finnish learner language, the findings of an earlier study on Estonian, German and Dutch learners' use of partitive predicatives (Spoelman 2010a) will then be outlined in order to introduce the current study and to put it in (a larger) perspective. 


\subsection{Predicative case-marking in Finnish and Estonian}

Finnish and Estonian belong to the Finnic languages, which are particularly well-known for their rich and complex morphology. The case systems of the closely related Finnish and Estonian language are very similar and both contain a partitive case. Finnish and Estonian have similar subject and object case alternations in which the partitive is used to indicate negative polarity and quantitative unboundedness as well as aspectual unboundedness in case of the object. There are, nevertheless, significant differences in the case-marking of Finnish and Estonian predicatives that will be outlined below.

A predicative is either an adjective phrase or a noun phrase functioning as the copula complement of a copula construction. In addition to a predicative, copula constructions involve a subject noun phrase (i.e. the referent of the predicative) and a copula verb. The prototypical copula verb is to be (olla in Finnish and olema in Estonian) (ISK 2004: \$944; EKK 1997: 409).

Aside from a marginal class of non-alternating predicatives indicating group inclusion or category membership (e.g. (1)), Finnish predicatives alternate between nominative and partitive case. This category of alternating predicatives is also called distributive predicatives. The Finnish predicative alternation is based upon the general principle that distributive predicatives express the divisibility of their referents and conform to their referents in number. Indivisible referents license a nominative predicative and divisible referents a partitive predicative (Vilkuna 1996: 105; ISK 2004: \$946). According to the divisibility distinction (cf. Chesterman 1991: 133), Finnish nouns are divided into two categories: singular count nouns denote an indivisible entity, while mass nouns, abstract nouns and plural NPs denote a divisible entity or set of entities (ISK 2004: \$555).

The Finnish predicative case alternation emerged as the result of a recent development during which the case-marking of distributive predicatives referring to a divisible subject gradually changed from nominative to partitive (Sadeniemi 1950). This development mainly took place 
during the second half of the 1800s, possibly under influence of the Swedish language (Denison 1957: 247). As a consequence, the nominative-partitive predicative alternation is typical of Finnish and not found in any of the other Finnic languages (Sadeniemi 1950).

Because of the lack of this predicative case alternation in Estonian, the occurrence of partitive predicatives is very limited in Estonian (Metslang 1994: 210; Erelt 2009) and limits itself to the marginal class of non-alternating predicatives expressing group inclusion or category membership also found in Finnish (Erelt 2003: 97-98). Estonian distributive predicatives bear nominative case, regardless of whether the referent denotes an indivisible entity, a divisible entity or a set of divisible entities (Denison 1957: 247).

The similarities and differences between Finnish and Estonian predicative case-marking are illustrated in examples (1)-(3). As illustrated in example (1), partitive predicatives expressing group inclusion or category membership occur in both Finnish and Estonian. In addition, singular count nouns take a nominative distributive predicative in either language (cf. ex. (2)). The differences can be inferred from example (3): While Estonian distributive predicatives always bear nominative case, Finnish distributive predicatives take partitive in case of a divisible entity. This can be either a mass noun denoting an unbounded entity (3a), an abstract referent (3b) or a plural referent (3c).

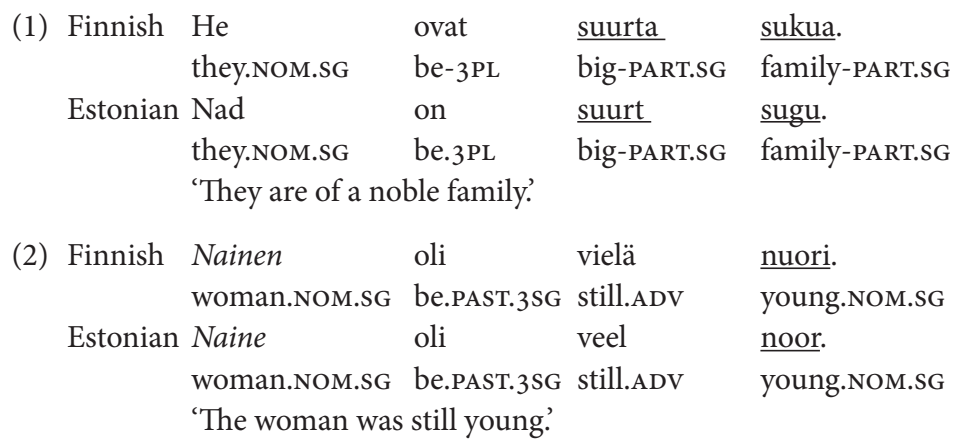




\begin{tabular}{|c|c|c|c|c|}
\hline \multirow{4}{*}{$\begin{array}{l}\text { (3a) Finnish } \\
\text { Estonian }\end{array}$} & Kahvi & on & \multicolumn{2}{|l|}{ hyvää. } \\
\hline & coffee.NOM.sG & be.3sG & \multicolumn{2}{|c|}{ good-PART.SG } \\
\hline & Kohv & on & \multicolumn{2}{|l|}{ hea. } \\
\hline & coffee.NOM.sG & be.3sg & \multirow{2}{*}{\multicolumn{2}{|c|}{ good.NOM.sG }} \\
\hline & 'Coffee is nice.' & & & \\
\hline (3b)Finnish & Opetus & on & \multicolumn{2}{|c|}{ tärkeää. } \\
\hline & teaching.NOM.sG & be.3sG & \multicolumn{2}{|c|}{ important-PART.SG } \\
\hline Estonian & Õpetus & on & \multicolumn{2}{|c|}{ tähtis. } \\
\hline & teaching.NOM.sG & be.3sG & \multicolumn{2}{|c|}{ important.NOM.sG } \\
\hline & \multicolumn{4}{|c|}{ 'Teaching is important.' } \\
\hline \multirow[t]{2}{*}{ (3c) Finnish } & Naiset & olivat & \multirow{4}{*}{$\begin{array}{l}\text { vielä } \\
\text { still.ADV } \\
\text { veel } \\
\text { still.ADV }\end{array}$} & nuoria. \\
\hline & woman-NOM.PL & be.PAST-3PL & & young-PART.PL \\
\hline Estonian & Naised & olid & & $\underline{\text { noored. }}$. \\
\hline & $\begin{array}{l}\text { woman-NOM.PL } \\
\text { 'The women were }\end{array}$ & $\begin{array}{l}\text { be.PAST-3PL } \\
\text { still young. }\end{array}$ & & young-NOM.PL \\
\hline
\end{tabular}

\subsection{The influence of the first language in foreign language learning}

The influence of the first language (L1) on the second (L2), commonly referred to as L1 influence, L1 transfer or crosslinguistic influence, has probably been one of the most extensively investigated SLA phenomena of the past few decades (Jarvis 2000). Studies on L1 influence have, however, largely focused on English as well as on some other major IndoEuropean languages, and not on genetically distant and typologically different languages as for example Finnish (Kaivapalu \& Martin 2007).

As a theoretical concept, L1 influence has continuously been tied in with the varying theoretical perspectives on SLA (Gass \& Selinker 1994: 53). In the heyday of Contrastive Analysis (CA), studies on L1 influence merely focused on errors and other instances of negative transfer (Jessner 2008). In the early 1970s, the highly influential morpheme order studies (e.g. Dulay \& Burt 1974) inspired researchers to advocate the claim that L2 acquisition resembled child L1 language acquisition so strongly that 
prior knowledge of the L1 could only play a very limited role in SLA, if any at all (Gass \& Selinker 1994: 79). At the end of the same decade, Kellerman (1977) was the first to approach L1 influence from a cognitive perspective, an approach that has been taken over by for example Ringbom $(1987 ; 2007)$ and Jarvis and Pavlenko (2010).

In this paper, L1 influence is also viewed as a cognitive phenomenon that emerges as a result of the L1-L2 similarities established by the learner. This view on the phenomenon of L1 influence implies that it is not objective similarity (i.e. the actual degree of congruence between languages) but subjective similarity (the degree of congruence learners perceive or assume to exist) that serves as the main driving force behind L1 influence. The nature of L1 influence can nevertheless be predicted on the basis of the overlap between subjective and objective L1-L2 similarities: Negative L1 influence occurs when subjective and objective similarities conflict, while positive L1 influence occurs when subjective and objective similarities are compatible. However, L1 influence often ends up being both positive and negative at the same time given that there is almost never a complete one-to-one correspondence between L1 and L2 features or phenomena (Jarvis \& Pavlenko 2010: 176-183). Partly as a consequence of this, it appears to be relatively rare that learners formulate crosslinguistic similarity hypotheses that are completely accurate (Ringbom \& Jarvis 2009). At least at the beginning stages of foreign language learning when their L2 knowledge is still limited, learners make frequent use of oversimplified equivalence hypotheses, i.e. L2 feature $\equiv$ L1 feature Because of the presence versus lack of L1-L2 similarities, it is more likely that learners from a closely related L1 background than learners from a typologically different L1 background establish (accurate) correspondence relations between their L1 and the L2 (Ringbom 2007).

As L1 influence is ultimately a subjective phenomenon (Ellis, 2008: 400) that can manifest itself in many different ways (e.g. overuse, errors, facilitation, preference, avoidance) (Odlin 2003) and can work differently in different linguistic subsystems (Jarvis \& Pavlenko 2010: 202), 
it is very challenging if not impossible to exactly predict the nature and likelihood of L1 influence. Also given the fact that the investigation of L1 influence has often lacked methodological rigor (cf. Jarvis 2000; 2010), it may not be surprising that studies on L1 influence have often provided contradictory findings.

The same holds true for studies on one the most important and at the same time one of the most complex factors affecting L1 influence, i.e. foreign language proficiency (Odlin 1989: 133-134). Although several studies have supported the widespread view that L1 influence decreases with increasing L2 proficiency, Jarvis (2000: 246-247) discusses evidence for altogether six different directions that L1 influence may take, i.e. L1 influence decreases, increases, nonlinearly decreases or increases, remains constant or continually fluctuates as L2 proficiency decreases. Jarvis and Pavlenko (2010: 202-203) claim that these contradictory findings are mainly due to substantial and significant differences in starting points and methodology. Foreign language proficiency has for example been defined and measured differently by different researchers. Jarvis and Pavlenko also argue that the fact that the studies differ in that some merely focus on negative L1 influence and others on both sides of L1 influence accounts for many of the contradictions. Negative L1 influence namely ultimately seems to decrease (generally to a point of stabilization) with increasing L2 proficiency, while a similar inverse relationship does not hold true for positive L1 influence (see also Odlin 1989: 133-134).

\subsection{Estonian learners' use of partitive predicatives}

The study discussed in this paper investigates the use of partitive predicatives in the written Finnish of Estonian learners of Finnish as a foreign language. The close genetic and typological relatedness between the two languages as well as the fact that the Finnish nominative-partitive predicative case alternation does not exist in Estonian namely create an excellent opportunity for L1 influence to occur in the L2 writings of Estonian learners. Finnish and Estonian are because of their genetic relationship 
namely not only broadly speaking very similar but the languages also have essentially similar subject and object case-marking conditions. These similarity relations could possibly cause Estonian learners to sometimes assume that Finnish and Estonian predicative case-marking principles are also (largely) interchangeable and cause them to use principles of Estonian predicative case-marking in Finnish. Such L1-L2 equivalence hypotheses could then result in either negative L1 influence (e.g. errors) or positive influence (e.g. facilitation).

The current study follows an earlier study (Spoelman 2010a) on the use of partitive predicatives in the written Finnish of Estonian, German and Dutch learners of Finnish as a foreign language. In this study, the Estonian learners represent learners from an L1 background closely related to Finnish and the German and Dutch learners two genetically distant and typologically different L1 backgrounds. Subsets of the International Corpus of Learner Finnish (Estonian learner corpus 90,236, German LC 32,300 and Dutch LC 46,670 words) served as the materials of this study. In the study, partitive predicatives were found to be significantly less frequently used by Estonian learners of Finnish than by native speakers of Finnish. A similar underuse of partitive predicatives was not observed from the German and Dutch learner corpora. The German and Dutch learners, in contrast, even tended to use partitive predicatives more frequently than native speakers of Finnish.

The significant underuse of partitive predicatives by the Estonian learners was revealed to be largely due to a large amount of partitive predicative underuse errors (contexts in which a partitive predicative was required but not realized). However, the German and Dutch learners' writings were also found to be characterized by a substantial amount of partitive predicative underuse errors. A more detailed analysis of these underuse errors nevertheless revealed conspicuous differences between the German and Dutch learners on the one, and the Estonian learners on the other hand. While the Estonian learners produced a relatively high amount of errors in which nominative plural was used instead of partitive plural, the German and Dutch learners appeared to use nominative 
singular (i.e. the basic non-inflected form) in such a way and to such an extent that they seemed to have often utilized it as a default predicative form. Still more evidence for the Estonian learners' remarkable use of partitive predicatives was found in that they almost completely failed to show any instances of partitive predicative overuse errors, while both substantial error frequencies and similar error patterns were observed from the German and the Dutch learner corpus. Thus, conspicuous differences were observed between the use of partitive predicatives by learners of Finnish from a very closely related L1 background (i.e. Estonian) and learners from distant L1 backgrounds (i.e. German and Dutch). Whereas the German and Dutch learners appeared to use Finnish predicatives in a more arbitrary way in that they for example tended to both overuse partitive predicatives and frequently used nominative singular as a default predicative form, the Estonian learners' use of partitive predicatives seemed to be influenced by L1 syntax. The research findings did not only suggest the negative influence of L1 syntax (e.g. in the frequent use of nominative plural instead of partitive plural predicatives), but evidence was also found for the occurrence of positive L1 influence (e.g. in the almost complete lack of partitive overuse errors which was not accordingly observed from the German and Dutch learner corpora). On a whole, the study thus indicated that the influence of Estonian predicative case-marking plays an important role in Estonian learners' use of Finnish partitive predicatives, simultaneously resulting in instances of both positive and negative L1 influence.

A recent classification of the texts of the Estonian learner corpus into the proficiency levels of the Common European Framework of Reference for Language (CEFR) paved the way for the more detailed analysis of the Estonian learners' use of partitive predicatives discussed in the present paper which addresses the question in what way increasing L2 proficiency affects the Estonian learners' use of partitive predicatives, and in particular those instances that indicate negative influence of L1 syntax. The current study as well as its preceding investigation (Spoelman 2010a) are both part of an ongoing research project on the 
use of partitive objects, subjects and predicatives in written Finnish learner language, of which the findings will come together as time progresses.

\section{Method}

For the purposes of this study, a subset of texts written by Estonian learners of Finnish (85,947 words) was selected from the International Corpus of Learner Finnish (ICLFI). The texts chosen to include were those written by native speakers of Estonian whose parents were also native speakers of Estonian. The ICLFI, a learner corpus initiated in 2007 (cf. Jantunen \& Piltonen 2009; Jantunen, this volume), comprises to date over 750,000 words of learners of Finnish as a foreign language from 22 different language backgrounds. The corpus consists of 22 subcorpora, each covering one of these language backgrounds. Although the corpus mainly consists of essays, other text types are also represented. A native-speaker reference corpus of approximately 2,7 million words was selected from the Native Finnish Corpus. The Native Finnish Corpus, compiled by Anna Mauranen as the native component of the Corpus of Translated Finnish, consists of professional writing and comprises academic texts, fiction, popular non-fiction and children's literature (cf. Mauranen 2000).

The texts of the Estonian learners were divided into different levels of proficiency ${ }^{1}$ according to the CEFR (2001), which involves six scales

The texts of the ICLFI were initially divided into levels of proficiency according to an indirect proficiency measure based on the amount of Finnish language contact hours received at university-level (beginning learner: less than 200 foreign language contact hours; intermediate learner: 200 to 400 language contact hours; advanced learner: more than 400 language contact hours). Currently, CEFR-evaluations are gradually being added to the corpus. Spoelman (2010b) discusses the advantages of a proficiency measure based on the CEFR scales over a measure based on language contact hours, hereby mainly touching upon construct validity, reliability and exactitude issues in comparing between (sub)corpora as well as the generalizability of research findings. Concerning the present study, CEFR-evaluations were merely based on a 
of $\mathrm{L} 2$ proficiency (A1-C2) arranged in three bands (basic, independent and proficient language user). All texts were holistically rated by a qualified and competent evaluator of L2 proficiency working for the Finnish National Certificate of Language Proficiency Examination (YKI). An overview of the classification of the Estonian learner corpus into CEFR levels of proficiency is provided in table 1.

TABLE 1. Estonian learner corpus structure

\begin{tabular}{|c|c|c|}
\hline Proficiency (CEFR) & Number of words & Percentage of total \\
\hline A1 & - & - \\
\hline A2 & 4,996 & $6 \%$ \\
\hline B1 & 39,053 & $45 \%$ \\
\hline B2 & 29,046 & $34 \%$ \\
\hline C1 & 9,333 & $11 \%$ \\
\hline C2 & 3,321 & $4 \%$ \\
\hline
\end{tabular}

Since both the learner corpus and the reference corpus consisted of raw texts, it was decided to linguistically annotate them according to a problem-oriented annotation and tagging procedure (cf. McEnery \& Wilson 2001: 69). With the help of a set of macros designed to automatically identify partitive forms and to simplify linguistic annotation, all partitive noun phrases were annotated and subsequently marked as partitive objects, partitive subjects, partitive predicatives or remaining partitives. The learner corpus was, furthermore, error-tagged on the occurrence of partitive overuse and underuse errors. Predicatives incorrectly bear-

single rater. However, the outcomes of the current study have already been confirmed in a succeeding and more methodology-oriented one (i.e. Spoelman 2011), in which a procedure is exemplified that has been invented to economically and systematically deal with CEFR-evaluations performed by a small even number of raters. This procedure is particularly suitable for small-scale studies and projects limited in duration and resources. 
ing partitive case were classified as partitive predicative overuse errors. Predicatives that required partitive case-marking but instead appeared in another case were classified as partitive predicative underuse errors.

The absolute frequencies of produced partitive predicatives, partitive predicative overuse errors and partitive predicative underuse errors were extracted from the corpus data with the help of WordSmith Tools 5.0 (Scott 2008). Obligatory Contexts (OCs) for partitive predicatives were subsequently calculated by adding up the number of correctly used partitive predicatives and the number of partitive underuse errors. OCs thus basically reflect the number of contexts that required a partitive predicative, regardless of whether or not this partitive was realized. Similarly, the frequencies of produced partitive predicatives plainly correspond to those contexts in which a partitive predicative was produced, regardless of whether or not produced correctly. Statistical comparisons between the frequencies of produced partitive predicatives and obligatory contexts for partitive predicatives observed from the learner corpus and the native Finnish reference corpus were drawn with the help of the Log-Likelihood chi-square. The $a$ decision level was set at 0.05 .

\section{Results}

\subsection{Frequency-error analysis on Estonian learners' use of partitive predicatives}

An overview of the use of partitive predicatives by the Estonian learners of Finnish at the different CEFR levels of proficiency is provided in figure 1. Figure 1 shows relative frequencies, which means that the frequencies of occurrence relate to the size of each subcorpus. The relative frequencies of partitive predicatives at level B1 were for example calculated by dividing the absolute occurrences by the size of the B1-level corpus (i.e. 39,053 ) and by multiplying the outcome by 100 . The utilization of relative frequencies enables the comparison between subcorpora and learner and reference corpora that are not equal in length. 
From figure 1, it can first be inferred that the Estonian learners' use of partitive predicatives steadily increases from almost 0 at level A2 to a relative occurrence of 1.11 at level C2. Similarly, the occurrence of obligatory contexts for partitive predicatives increases from a marginal 0.20 to 1.29 . A relative occurrence of partitive predicatives of 0.83 was observed from the native Finnish reference corpus. Statistical testing (Log-Likelihood chi-square) revealed that the Estonian learners' use of partitive predicatives was at the levels A2 (LL $=68.98 ; p=.0001), \mathrm{B} 1$ (LL $=163.21 ; p=.0001)$ and $\mathrm{B} 2(\mathrm{LL}=14.91 ; p=.001)$ significantly less than that of the native speakers as a whole. In addition, obligatory contexts for partitive predicatives were revealed to occur significantly less frequently at the Estonian learners' level B1 ( $\mathrm{LL}=35.52 ; p=.0001)$ and B2 (LL $=20.21 ; p=.0001)$ than they appeared in the native-speaker reference corpus. From level $\mathrm{C} 1$ onward, obligatory contexts started to occur significantly more frequently than in the reference corpus $(\mathrm{C} 1: \mathrm{LL}=7.30$, $p=.001 ; \mathrm{C} 2: \mathrm{LL}=6.85, p=.001)$.

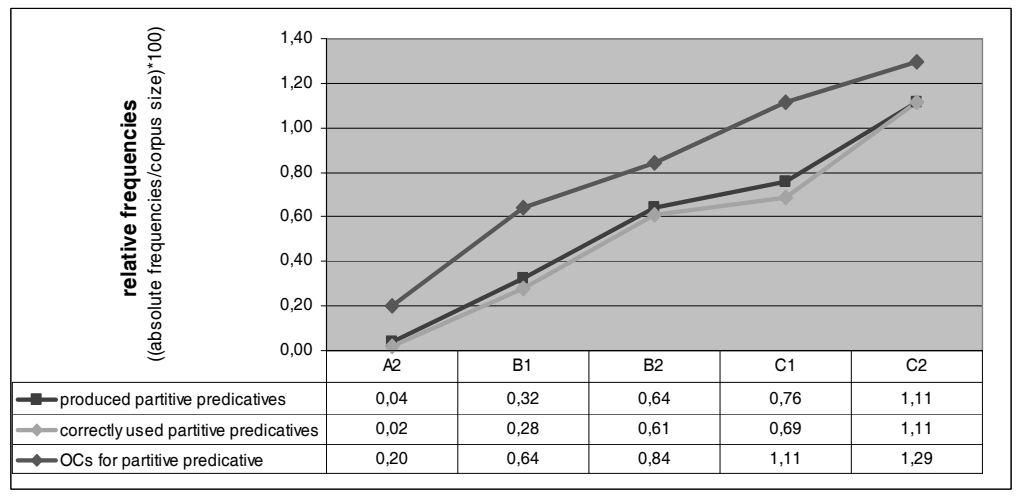

FIGURE 1. Estonian learners' use of partitive predicatives at different levels of L2 proficiency 
Another component that can be derived from figure 1 is the occurrence of errors across the different CEFR levels of proficiency. The relative occurrence of partitive overuse and underuse errors is namely covertly represented in that the difference between produced and correctly used partitive predicatives parallels the frequency of partitive overuse errors, whereas the difference between OCs and correctly used partitive predicatives equals the frequency of partitive underuse errors. As for the development of error patterns, figure 1 indicates that partitive predicative underuse errors do not decrease as L2 proficiency increases (A2 0.18; B1 0.36; B2 0.23; C1 0.42 and C2 0.18). Furthermore, figure 1 illustrates that partitive predicative overuse errors are relatively absent at most proficiency levels (A2 0.02; B1 0.04; C1 0.07) and even entirely missing at level C2.

\subsection{Detailed analysis on the occurrence of partitive predicative underuse errors}

In addition to the general frequency-error analysis on the Estonian learners' use of partitive predicatives at different levels of L2 proficiency, a detailed analysis was conducted on the development of partitive predicative underuse error patterns. Figure 2 shows the occurrence of the three main underuse error categories as a function of L2 proficiency. In this figure, the error categories are represented as percentages of the total number of partitive predicative underuse errors at each level of proficiency; the graph thus illustrates the developmental pattern of partitive predicative underuse errors.

As can be clearly inferred from figure 2, the proportion of partitive underuse errors in which nominative plural was used instead of partitive plural substantially and gradually decreases with increasing L2 proficiency. At level C2 there even appeared to be a complete lack of errors in which nominative plural was used instead of partitive plural. In contrast, the proportion of errors in which partitive singular predicatives were replaced by nominative singular predicatives was found to 
steadily increase as L2 proficiency increases. The use of nominative singular instead of partitive plural appeared to represent a partitive underuse error category only marginally occurring at level B1 and B2.

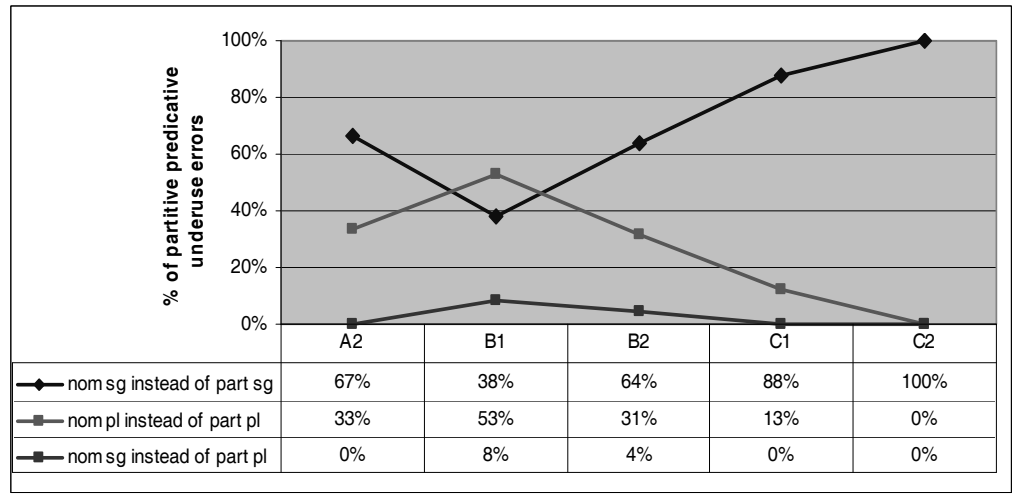

FIGURE 2. The occurrence of partitive predicative underuse errors at different levels of L2 proficiency

\section{Discussion}

As an earlier study (Spoelman 2010a) revealed conspicuous differences between Estonian learners' use of Finnish partitive predicatives on the one hand and German and Dutch learners' use of partitive predicatives on the other, it was decided to conduct a study with special reference to Estonian learners of Finnish at different levels of L2 proficiency. The purpose of the present study was to provide additional insights into the role of the L1 in the Estonian learners' use of partitive predicatives and to explore the relationship between L1 influence and L2 proficiency. Research materials (85,749 words) were selected from the Estonian subcorpus of the International Corpus of Learner Finnish (ICLFI) and divided into proficiency levels according to the proficiency scales of the CEFR. A combined frequency-analysis was conducted in which mainly relative frequencies were calculated (i.e. absolute frequencies 
related to the corpus sizes). In this manner, comparisons could be drawn between frequencies of occurrence observed at the different levels of L2 proficiency (i.e. A1-C2) as well as between frequencies of occurrence extracted from the learner corpus on the one hand and the native Finnish reference corpus or the other hand.

From the conducted frequency-error analysis, it was revealed that, until level B2, the Estonian learners of Finnish used significantly fewer partitive predicatives than the native speakers of Finnish. At level A2 and B1, obligatory contexts for partitive predicatives were also found to occur significantly less frequently than in the reference corpus, while from level $\mathrm{C} 2$ onwards this turned to be the other way around. These findings suggest that, starting from a highly significant underuse of partitive predicatives at the lower levels of L2 proficiency, the Estonian learners' use of partitive predicatives gradually became more native-like as L2 proficiency increased. Although the findings seem to indicate avoidance of partitive predicatives at the lower proficiency levels, I would alternatively argue that the gradual increase of partitive predicatives across increasing levels of proficiency is actually inherently linked to the increasing development of overall complexity and syntactic complexity. Partitive predicatives referring to an abstract referent (e.g. Matkustaminen on ihanaa 'Travelling is great') namely steadily increase from zero at level A2 to a relative occurrence of 0.15 at level C2. In a similar vein, partitive predicatives referring to a dependent clause or infinitival construction (e.g. On mielenkiintoista, että (...) On mielenkiintoista opiskella ulkomailla 'It is interesting that $(\ldots) \sim$ It is interesting to study abroad') even gradually increase from zero at $\mathrm{A} 2$ to 0.50 at $\mathrm{C} 1$ and 0.84 at $\mathrm{C} 2$ and thus come to represent the majority of partitive predicatives.

As for the occurrence of errors, the prevalence of partitive predicative overuse errors was found to be very low at all levels of proficiency. At level C2, there was even a complete lack of overuse errors. These outcomes are in line with the low overall frequency of partitive predicative overuse errors in the preceding study (Spoelman 2010a) and provide additional evidence for the suggestion made in the earlier study that the virtual 
absence of partitive predicative overuse errors is an instance of positive L1 influence resulting from the fact that because of the extremely limited occurrence of partitive predicatives in Estonian possible overgeneralized equivalence hypotheses (i.e. $\mathrm{L} 1 \equiv \mathrm{L} 2$ ) cannot possibly lead to the occurrence of partitive predicatives in Estonian learners' Finnish.

Considering underuse errors, the analysis indicated that the occurrence of partitive predicative underuse errors did not decrease with gains in L2 proficiency. Assuming that at least some of these errors represent instances of negative L1 influence, this seems to point to the direction that negative L1 influence does not decrease with increasing L2 proficiency but, instead, remains fairly stable. Although this would probably be in line with the studies discussed by Jarvis (2000) indicating such a rather constant relationship between L1 influence and L2 proficiency, it would not be in line with the widespread assumption that at least negative L1 influence ultimately decreases with gains in L2 proficiency (cf. Odlin 1989: 133-134).

Nevertheless, a more detailed analysis of the partitive predicative underuse errors has provided more special insight into this matter. Errors in which nominative plural was used instead of partitive plural namely appeared to steadily decrease until a complete absence at level $\mathrm{C} 2$, while errors in which partitive singular was replaced by nominative singular increased with gains in L2 proficiency. I would argue that underuse errors of the former type mainly indicate instances of negative L1 influence. As illustrated in example (4), morphosyntactically similar constructions would namely be fully grammatically correct in Estonian. The ultimate decrease of underuse errors of this type would then be completely in line with the widespread assumption (cf. Odlin 1989: 133-134; Jarvis 2000) of an inverse relationship between L2 proficiency and negative L1 influence. 
(4) Target-like structure

He ovat onnellisia.

they.Nom be-3PL happy-PART.PL

'They are happy'

Produced structure

He ovat ${ }^{\star}$ onnelliset.

they.NOM be-3PL happy-* NOM.PL

'They are happy'

Equivalent structure in Estonian

Nad

on

õnnelikud.

they.NOM be.3PL happy-NOM.PL

'They are happy'.

As opposed to L1 influence (interlingual influence), it could possibly have been mainly intralingual influence (e.g. overgeneralization of L2 rules) that has resulted in errors in which partitive singular was replaced by nominative singular, taking into consideration that the principles of Finnish singular predicative case-marking are far less straightforward and opaque than those of plural predicative case-marking. Singular predicatives namely also involve predicatives referring to a dependent clause or infinitival construction, which show considerable variation in terms of predicative case-marking. Although nominative is assigned in most cases, there are also adjectives that solely (or alternatively) appear in partitive when referring to dependent clause or infinitival construction (cf. example (5). A similar trend holds true for referents denoting a (singular) abstract entity: Most abstract referents license partitive predicatives but some allow both nominative and partitive predicatives (cf. Vilkuna 1996: 105-107; ISK 2004: \$555, \$954). This variation in Finnish singular predicative case-marking probably regularly causes learners of Finnish as a foreign language to overgeneralize some of these L2 rules. As for Estonian learners of Finnish, it would be likely that they would favour nominative predicatives because of the existing L1-L2 similarities. 
The prevalence of errors in which nominative singular was used to replace partitive singular would then not just have been triggered by intralingual influence but rather by a complex interplay between interand intralingual influence (cf. Ringbom 1987: 60).

(5) Onko erikoista ( ${ }^{*}$ erikoinen) / kiva $\sim$ kivaa /

be.3SG-QP special-PART.SG $\sim{ }^{*}$ NOM.SG / nice.NOM.SG $\sim$ PART.SG /

hyvä $\left(\sim^{*}\right.$ hyvää $) \quad$ opiskella ulkomailla?

good.NOM.SG $\sim{ }^{*}$ PART.SG study abroad

'Is it special / nice / good to study abroad?'

\section{Conclusions, implications and further research}

To conclude, the current study has provided valuable insights into the use of partitive predicatives by Estonian learners at different levels of L2 proficiency as well as into the nature of L1 influence in general. Supporting earlier research findings (Spoelman 2010a) as well as the claim that L1 influence generally ends up being both positive and negative at the same time (Jarvis \& Pavlenko 2010: 176-183), the combined frequencyerror analysis indicated both instances of positive L1 influence and negative L1 influence. As for the occurrence of partitive predicative underuse errors in which nominative plural was used instead of partitive plural, these errors were found to ultimately decrease with increasing L2 proficiency, providing additional evidence for the existence of an inverse relationship between negative L1 influence and L2 proficiency. The use of nominative singular instead of partitive singular appeared to represent a partitive predicative underuse error category that persists even with gains in L2 proficiency. This error category may probably be due to a complex interaction between L1 influence and certain overgeneralizations of L2 rules triggered by the intransparency of rules concerning the case-marking of predicatives referring to dependent clauses, infinitival constructions and abstract entities. The outcomes of the study indicate that the teaching of partitive predicatives to Estonian learners of Finnish would benefit from both emphasizing similarities and differences in 
Finnish and Estonian predicative case-marking and from shedding light on less transparent and consistent rules in Finnish partitive predicative case-marking.

Still adding to the outcomes discussed in the preceding paragraph that the development of the Estonian learners' use of partitive predicatives (i.e. from a highly significant underuse to close to native-like use) seemed to be inherently linked to the development of complexity and syntactic complexity, the research findings of this study altogether support the view that the phenomenon of L1 influence is both multifaceted as well as extremely complex in nature (cf. Dechert \& Raupach 1989). As further studies to be conducted within the framework of this research project do not only focus on partitive predicatives but also on learners' use of partitive objects and partitive subjects, it can be expected that the project will altogether present a more overall picture of the role of the first language in foreign language learning (particularly syntax) as well as its affecting factors, hereby contributing a better understanding of the complex nature of the phenomenon of L1 influence.

\section{Abbreviations}

$\begin{array}{ll}3 & \text { 3rd person } \\ \text { ADV } & \text { adverb } \\ \text { NOM } & \text { nominative } \\ \text { PART } & \text { partitive } \\ \text { PAST } & \text { past } \\ \text { PL } & \text { plural } \\ \text { QP } & \text { question particle } \\ \text { SG } & \text { singular }\end{array}$




\section{References}

Chesterman, Andrew 1991. On Definiteness: A study with Special Reference to English and Finnish. Cambridge: Cambridge University Press. doi:10.1017/ CBO9780511519710

CEFR $=$ Common European Framework of Reference for Languages: Learning, teaching, assessment. Council of Europe. Cambridge: Cambridge University Press, 2001.

Dechert, Hans W., Manfred Raupach 1989. Introduction. - Hans W. Dechert, Manfred Raupach (Eds.). Transfer in Language Production. Norwood NJ: Ablex Publishing, ix-xvii.

Denison, Norman 1957. The partitive in Finnish. Annales Academiae Scientiarum Fennicae B 108, 262. Helsinki: Suomalainen Tiedeakatemia.

Dulay, Heidi, Marina Burt 1974. Natural sequences in child Second Language Acquisition. - Language Learning 24 (1), 37-53. doi:10.1111/j.14671770.1974.tb00234.x

EKK = Erelt, Mati, Tiiu Erelt, Kristiina Ross 1997. Eesti keele käsiraamat. Tallinn: Eesti Keele Sihtasutus.

Ellis, Rod 2008. The Study of Second Language Acquisition. 2nd edition. Oxford: Oxford University Press.

Erelt, Mati 2003. Structure of the Estonian language: Syntax. - Mati Erelt (Ed.). Estonian Language. Linguistica Uralica Supplementary Series 1. Tallinn: Estonian Academy, 93-129.

Erelt, Mati 2009. Typological overview of Estonian syntax. - Sprachtypologie und Universalienforschung: Language Typology and Universals 62 (1-2), 6-28. doi:10.1524/stuf.2009.0002

ISK 2004 = Hakulinen, Auli, MariaVilkuna, Riitta Korhonen, Vesa Koivisto, Tarja Riitta Heinonen, Irja Alho 2004. Iso suomen kielioppi. Suomalaisen Kirjallisuuden Seuran toimituksia 950. Helsinki: Suomalaisen Kirjallisuuden Seura.

Gass, Susan, Larry Selinker 1994. Second Language Acquisition: An Introductory Course. Hillsdale, NJ: Lawrence Erlbaum Associates.

Jantunen, Jarmo H., Sanna Piltonen 2009. Oppijansuomen ja -viron sähköiset tutkimusaineistot. - Virittäjä 113, 449-458.

Jantunen, Jarmo H., this volume. Kansainvälinen oppijansuomen korpus (ICLFI): typologia, taustamuuttujat ja annotointi. - Lähivõrdlusi. Lähivertailuja 21, 86-105. 
Jarvis, Scott 2000. Methodological rigor in the study of transfer: Identifying L1 influence in the interlanguage lexicon. - Language Learning 50 (2), 245309. doi:10.1111/0023-8333.00118

Jarvis, Scott 2010. Comparison-based and detection-based approaches to language transfer. - EUROSLA Yearbook 10 (1), 169-192. doi:10.1075/ eurosla.10.10jar

Jarvis, Scott, Aneta Pavlenko 2010. Crosslinguistic Influence in Language and Cognition. New York, London: Routledge.

Jessner, Ulrike 2008. Teaching third languages: Findings, trends and challenges. Language Teaching 41 (1), 15-56. doi:10.1017/S0261444807004739

Kaivapalu, Annekatrin, Maisa Martin 2007. Morphology in transition: Plural inflection of Finnish nouns by Estonian and Russian learners. - Acta Linguistica Hungarica 54 (2), 129-156. doi:10.1556/ALing.54.2007.2.2

Kellerman, Eric 1977. Towards a characterization of the strategy of transfer in second language learning. - Interlanguage Studies Bulletin 2, 58-145.

Kiparsky, Paul 1998. Partitive case and aspect. - Miriam Butt, William Geuder (Eds.). The Projection of Arguments: Lexical and Compositional Factors. Stanford: CSLI, 265-308.

Mauranen, Anna 2000. Strange strings in translated language: A study on corpora. - Maeve Olohan (Ed.). Intercultural Faultlines. Research Models in Translation Studies 1: Textual and Cognitive Aspects. Manchester: St. Jerome Publishing, 119-141.

McEnery, Tony, Andrew Wilson 2001. Corpus Linguistics. 2nd edition. Edinburgh: Edinburgh University Press.

Metslang, Helle 1994. Kielet ja kontrastit. - Virittäjä 98, 203-226.

Odlin, Terence 1989. Language Transfer. Cross-linguistic Influence in Language Learning. Cambridge: Applied Linguistics.

Odlin, Terence 2003. Crosslinguistic influence. - Michael H. Long, Catherine J. Doughty (Eds.). The Handbook of Second Language Acquisition. Oxford: Blackwell Publishing Ltd, 436-486.

Ringbom, Håkan 1987. The Role of the First Language in Foreign Language Acquisition. Clevedon: Multilingual Matters.

Ringbom, Håkan 2007. Cross-linguistic Similarity in Foreign Language Learning. Clevedon: Multilingual Matters.

Ringbom, Håkan, Scott Jarvis 2009. The importance of cross-linguistic similarity in foreign language learning. - Michael H. Long, Catherine J. Doughty (Eds.). Handbook of Language Teaching. Hoboken: Wiley-Blackwell, 116-128. 
Sadeniemi, Matti 1950. Totaalisesta ja partiaalisesta predikatiivista. - Virittäjä 54, 46-53.

Scott, Mike 2008. WordSmith Tools version 5. Liverpool: Lexical Analysis Software.

Schot-Saikku, Päivi 1990. Der Partitiv und die Kasusalternation: Zum Fall Partitiv in der Finnischen Syntax. Hamburg: Buske.

Spoelman, Marianne 2010a. The copula construction in Finnish learner language: Estonian, German and Dutch learners' use of partitive predicatives. - Pille Eslon, Katrin Õim (Toim.). Korpusuuring ja meetodid. Tallinna Ülikooli eesti keele ja kultuuri instituudi toimetised 12. Tallinn: TLÜ Kirjastus, 127-152.

Spoelman, Marianne 2010b. The use of the partitive case in Finnish learner language: The operationalization of foreign language proficiency. - Presentation held during the workshop Methodology in Learner Corpus Research, at the annual conference of the Linguistic Association of Finland in Vaasa, November 13-14, 2010.

Spoelman, Marianne 2011. Foreign language proficiency ratings based on the Common European Framework of Reference for languages: Dealing with inter-rater variability in small-scale studies. - Presentation held during a workshop of the ICLFI-project held in Umeå, March 8-9, 2011.

Vilkuna, Maria 1996. Suomen lauseopin perusteet. Helsinki: EDITA.

\section{Marianne Spoelman}

Finnish as a Second and Foreign Language, Faculty of Humanities

P.O. Box 1000

FI-90014 University of Oulu, Finland

marianne.spoelman@oulu.fi 


\title{
Kohdekielen eri tasoilla olevien virolaisten suomenoppijoiden partitiivipredikatiivin käyttö
}

\author{
MARIANNE SPOELMAN \\ Oulun yliopisto
}

Partitiivin käyttö aiheuttaa suomea toisena ja vieraana kielenä oppiville usein ongelmia. Tässä korpustutkimuksessa, joka on osa suurempaa suomenoppijoiden partitiivin käyttöön kohdistuvaa tutkimushanketta, tutkitaan suomea vieraana kielenä oppivien virolaisten partitiivipredikatiivin käyttöä lähde- ja kohdekielen samanlaisuuden ja erilaisuuden näkökulmasta.

Vaikka suomi ja viro ovat läheisiä sukukieliä, joiden objektin ja subjektin sijanvaihtelut ovat suurin piirtein samanlaisia, virosta puuttuu suomen kielessä esiintyvä predikatiivin sijanvaihtelu. Suomen kaltainen partitiivimuotoinen predikatiivi esiintyy virossa vain inkluusiorakenteessa (esim. He ovat suurta sukua $\sim$ Nad on suurt sugu). Muissa tapauksissa viron predikatiivi on nominatiivissa silloinkin, kun subjektin tai predikatiivin tarkoite on jaollinen. Esimerkkejä:

viro

Naine oli veel noor (NOM.SG)

Kohv on hea (NOM.SG)

Naised olid veel noored (NOM.PL)

Käärid on teravad (NOM.PL) suomi

Nainen oli vielä nuori (NOM.SG)

Kahvi on hyvää (PART.sG)

Naiset olivat vielä nuoria (PART.PL)

Sakset ovat terävät (NOM.PL)

Tutkimuksen tavoitteena on ensinnäkin selvittää, miten lähdekieli vaikuttaa virolaisten suomenoppijoiden partitiivipredikatiivin käyttöön, ja toiseksi tutkia, miten lähdekielen vaikutus ja kielenoppijan saavuttama kielitaidon taso suhteutuvat toisiinsa.

Tutkimusaineistoina on virolaisten suomenoppijoiden kirjoittamista teksteistä koostuva oppijankielen korpus $(85,749$ sanetta). Kaikki nämä tekstit poimittiin Kansainvälisestä oppijansuomen korpuksesta (ICLFI) ja arvioitiin 
Eurooppalaisen viitekehyksen (CEFR) kielitaitotasojen mukaan. Tutkimusaineistot jaettiin viidelle kielitaitotasolle: A2, B1, B2, C1 ja C2. Vertailukorpuksena käytettiin suomea äidinkielenään puhuvien kirjoittamista teksteistä koostuvaa aineistoa (n. 2,7 milj. sanetta), joka poimittiin Natiivisuomen korpuksesta (Mauranen 2000).

Tutkimustulokset osoittivat, että oppijoiden lähdekieli vaikuttaa selvästi partitiivipredikatiivin käyttöön. Joissakin tapauksissa lähdekielen vaikutus osoittautui positiiviseksi, joissakin negatiiviseksi. Positiivista lähdekielen vaikutusta heijasti muun muassa partitiivin ylikäyttövirheiden vähäisyys. Negatiivinen lähdekielen vaikutus taas ilmeni esim. siten, että monikon nominatiivia monesti käytettiin monikon partitiivin asemesta (esim. Naiset olivat vielä nuoret). Jälkimmäisen virhetyypin ja kohdekielen taitotason välillä näytti olevan selvä negatiivinen korrelaatio, mikä viittaa siihen, että negatiivinen lähdekielen vaikutus vähentyy kielitaidon lisääntymisen myötä. Ilmiönä lähdekielen vaikutus näyttää kuitenkin olevan monimutkaisempi ja monipuolisempi, sillä kuten jotkut tulokset jo osoittavat, lähdekielen vaikutus voi myös olla vuorovaikutuksessa monien muidenkin ilmiöiden ja muuttujien kanssa.

Avainsanat: lähdekielen vaikutus; oppijankieli; korpustutkimus; partitiivi; predikatiivirakenne; suomi; viro 